\title{
Collaborative Governance of Coral Reef Management and Rehabilitation in Tsunami Disaster Mitigation Efforts
}

\author{
Dodi Robby Hari Ismanto ${ }^{1}$, Rachma Fitriati ${ }^{2}$ \\ Magister Administrasi Dan Kebijakan Publik, Fakultas Ilmu Administrasi, Universitas Indonesia \\ Email: dody.robby@gmail.com ${ }^{1}$, rachmafi@yahoo.com²
}

(Received: December 12-2019; revised: February 15-2019; published: June 31-2020)

\begin{abstract}
The tsunami is the biggest threat to countries around the world tectonic plates and the ring of fire, including Indonesia. The impact of economic losses and heavy casualties made the tsunami worth watching out. Ecosystem-based tsunami disaster mitigation efforts are deemed necessary, considering that $2 / 3$ of Indonesia consists of the sea. The coral reef is one of the coastal ecosystems that can reduce tsunami waves by up to $50 \%$ before it hits coastal areas. However, the current condition of coral reefs is very alarming due to the actions of irresponsible humans. Collaboration between stakeholders is needed to carry out ecosystem-based tsunami disaster mitigation efforts. Collaborative governance becomes an essential issue in efforts to build and improve services in the public sector by involving all relevant stakeholders. The sectoral ego of the stakeholders is no longer relevant to be maintained because each actor has their strengths and weaknesses. Collaboration between actors framed in a collaboration platform by having a principled engagement, shared motivation, and collective capacity will produce better results.
\end{abstract}

Keywords: Tsunami; Collaborative Governance; Mitigation; Coral Reef

\section{INTRODUCTION}

The natural disasters phenomenon of earthquake and tsunami that occurred in Indonesia some time lately has received attention from various parties and must be anticipated by all stakeholders (Amagai et al., 2014; Bragg et al., 2018; Neumayer \& Plümper, 2007; Sorooshian, 2005; Yamamura, 2013; Yanagisawa et al., 2016). Disaster mitigation efforts are essential because Indonesia's geographical location is in areas prone to earthquakes and tsunamis. Astronomically, Indonesia as an archipelago state is known as the "Emerald of Equator," positioned at $07^{\circ} \mathrm{N}-12^{\circ} \mathrm{S}$ and $95^{\circ} \mathrm{E}-141^{\circ} \mathrm{E}$ Longitude. This position makes Indonesia has a tropical climate that has enough rainfalls which make it a fertile land.

Tropical forests flourish in Indonesia, which stores both biological and animal richness. Geographically, Indonesia is also in a strategic position, placed between 2 continents (Asia and Australia) and two oceans (Indian and Pacific). Geologically, Indonesia, which is located around 3 (three) tectonic plates, namely Indo-Australia, Eurasia, and the Pacific which collide with each other and produce magma activity in the bowels of the earth. Indonesia's territory that is passed by the tectonic plate is mostly located on the south side or in the Pacific Ocean, as can be seen in Figure 1.

The boundary area between tectonic plates where the intersecting plates are areas that have active tectonic conditions, and when one tectonic plate moves, it can cause earthquakes, magma activity in the bowels of the earth increases. This magma activity became the forerunner to the birth of 127 active volcanoes in Indonesia. Rows of volcanoes that circle the Pacific 
168 | Jurnal Ilmiah Ilmu Administrasi Publik: Jurnal Pemikiran dan Penelitian Administrasi Publik Volume 1o Number 1, January - June 2020. Page 1-14

Ocean, known as the Ring of Fire and Indonesia, are located in the area (Figure 2). The geological location and its position in the area around the Ring of Fire make Indonesia vulnerable to natural disasters: earthquakes and tsunamis.

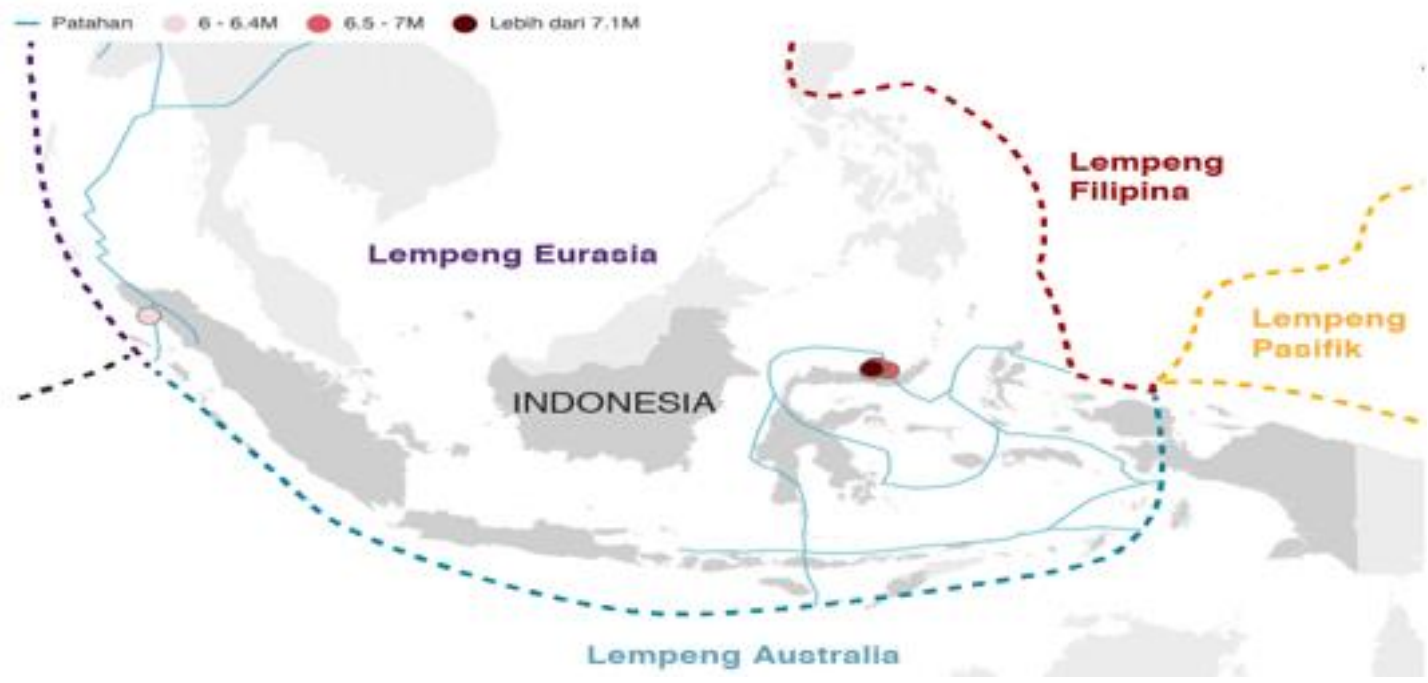

Source: US Geological Survey (USGS)

Figure 1

Plate Tectonics

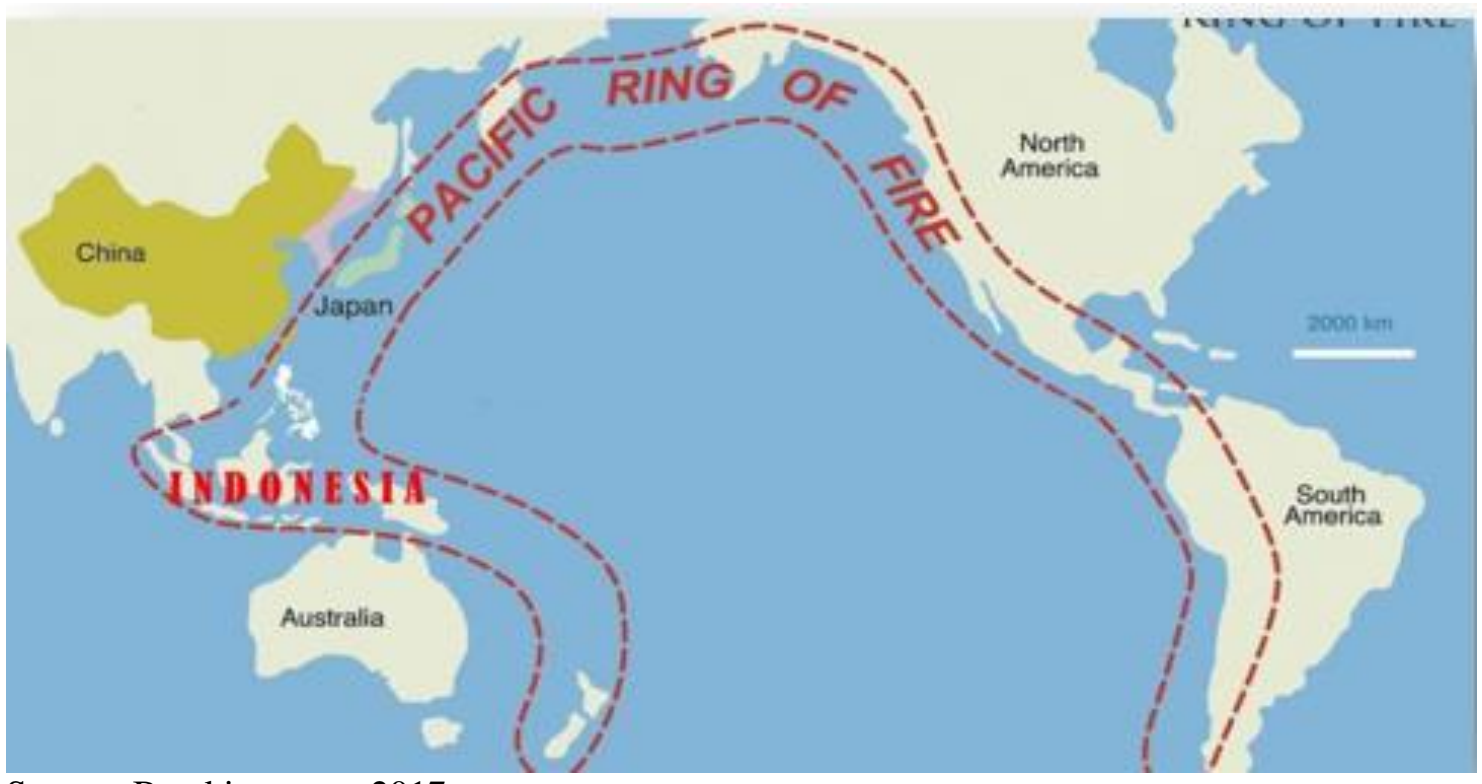

Source: Breakingnews, 2017

Figure 2 Pacific Ring of Fire 
The tsunami is one of the natural disasters caused by massive waves of seawater. This wave can move in all directions reaching thousands of kilometers with the speed comparable to jet planes and eventually hit the land - no wonder the land that was hit by the tsunami will be destroyed in a short time. Porter et al., (1967) said that a tsunami is a giant wave phenomenon which sweeps the land, this phenomenon can occur due to earthquakes or large-scale disruption under the sea, such as underwater landslides or volcanic eruptions in the sea.

President Joko Widodo, in the BNPB National Coordination Meeting in Surabaya, said that natural disasters were not only earthquakes, tsunamis, and landslides, but earthquake and tsunami were the type of natural disasters that caused the most damage and fatalities. History records, from 1964 to 2019 , there were at least 25 tsunami incidents that had occurred in Indonesia, namely:

Table 1

Tsunami History in Indonesia

\begin{tabular}{|c|l|c|c|c|}
\hline Year & \multicolumn{1}{|c|}{ Location/ Year } & $\begin{array}{c}\text { Strength } \\
(\mathbf{S R})\end{array}$ & $\begin{array}{c}\text { Tsunami } \\
\text { Height }\end{array}$ & $\begin{array}{c}\text { Victims } \\
\text { (people) }\end{array}$ \\
\hline 1961 & Flores & n/a & & $110 / 479$ \\
\hline 1964 & Sumatra & n/a & & 71 \\
\hline 1965 & Seram-Maluku & 7,5 & $4 \mathrm{~m}$ & $58 / 100$ \\
\hline 1967 & Tinabung-Sulsel & 5,8 & $8-10$ & 392 \\
\hline 1968 & Tambo-Sulteng & 7,4 & $10 \mathrm{~m}$ & $64 / 97$ \\
\hline 1969 & Majene-Sulawesi & 6,9 & $10 \mathrm{~m}$ & 316 \\
\hline 1977 & Sumba & 7 & 15 & $2 / 25$ \\
\hline 1977 & NTT, Flores, Pulau Atauro & $\mathrm{n} / \mathrm{a}$ & & $27 / 200$ \\
\hline 1979 & NTB, Bali, Lombok, Sumbawa & $\mathrm{n} / \mathrm{a}$ & & $13 / 400$ \\
\hline 1982 & Larantuka & 5,9 & & $83 / 108$ \\
\hline 1987 & NTT, Flores Timur, Pulau Pantar & $\mathrm{n} / \mathrm{a}$ & & 7 \\
\hline 1989 & NTT, Pulau Alor & $\mathrm{n} / \mathrm{a}$ & $\mathrm{n} / \mathrm{a}$ & $1952 / 2126$ \\
\hline 1992 & NTT, Flores, Pulau Babi & 7,5 & $11,2-26,2$ & $38 / 400$ \\
\hline 1994 & Banyuwangi, Jawa Timur & 6,8 & 19,1 & $3 / 68$ \\
\hline 1996 & Palu, Sulawesi Tengah & 7,7 & $6 \mathrm{~m}$ & 160 \\
\hline 1996 & Biak, Papua & 8 & 13,7 & 34 \\
\hline 1998 & Taliabu, Maluku & 7,7 & $3 \mathrm{~m}$ & $4 / 54$ \\
\hline 2000 & Banggai, Sulawesi Tengah & 6,5 & $3 \mathrm{~m}$ & $230.000 / 250.000$ \\
\hline 2004 & Aceh & $9,1-9,3$ & $34,5 \mathrm{~m}$ & 310 \\
\hline 2005 & Nias & 8 & $3,5 \mathrm{~m}$ & 668 \\
\hline 2006 & Pangandaran & 7,7 & $8,25 \mathrm{~m}$ & 21 \\
\hline 2007 & Bengkulu & 8,4 & $3,8 \mathrm{~m}$ & 413 \\
\hline 2010 & Mentawai & 7,2 & $7 \mathrm{~m}$ & 2000 \\
\hline 2018 & Palu \& Donggala & 7,4 & $11 \mathrm{~m}$ & 437 \\
\hline 2018 & Selat Sunda & - & $2-5 \mathrm{~m}$ & \\
\hline & & $-50 u$ & \\
\hline
\end{tabular}

Source: processed by authors from various sources 
170 Jurnal Ilmiah Ilmu Administrasi Publik: Jurnal Pemikiran dan Penelitian Administrasi Publik Volume 10 Number 1, January - June 2020. Page 1-14

The losses incurred due to the tsunami are huge. PT Jababeka Tbk as the manager of Tanjung Lesung Special Economic Zone (SEZ) where the area is one of the most affected locations of the Sunda Strait Tsunami which occurred at the end of 2018, said that it suffered a loss of Rp. 150 billion due to the lunge of the Sunda Strait tsunami. The CEO of PT Jababeka Tbk said that the tsunami damaged at least $30 \%$ of the buildings managed by its subsidiaries. In line with Setyono, Chairman of the Indonesian Hotel and Restaurant Association (IHRA), Achmad Sari Alam said hoteliers on the west coast of Banten were estimated to suffer losses due to the tsunami of no less than Rp. 10 billion. Not to mention the loss from the social aspects that hit communities around the coast affected by the tsunami, as well as casualties caused. The community was torn apart, and everything was lost in a short time, livelihoods were lost, families were scattered and even lost and died, the tsunami destroyed public facilities. This enormous tsunami damage certainly requires a relatively long time and a high cost to recover from the situation as before.

More comprehensive, joint, and sustainable disaster mitigation efforts must be made immediately. Bumgarner (2008) argues that "mitigation" relates to all activities aimed at eliminating or reducing the level of long-term risk to human life and property from natural and technological hazards. In line with that, Bullock et al., (2011) defines mitigation as a means to reduce impacts and can be defined as sustainable actions to reduce or eliminate the risk of people and property from these hazards and effects. In carrying out disaster mitigation efforts, Rossi, Wright, and Rossi et al., (1982) explain that there are 2 (two) ways that can be done in disaster mitigation efforts. The first is structural mitigation, which can be exemplified, such as the construction of dams, embankments, sea walls (seawalls) and other obstacles that are permanent and intended to prevent sea waves from reaching the land, the creation of facilities and infrastructure for emergency response and early warning systems. Second is non-structural mitigation, which is an effort beyond structural mitigation that can be done, including mitigation policy making, urban spatial planning, community capacity building, reviving community activities and awareness, including awareness of the importance of coastal ecosystems.

One of the structural mitigation efforts ever undertaken by the government was the installation of buoys. A buoy is a tool to detect changes in tidal waves or tsunamis installed in the middle of the sea and is the fastest early detection technology at this time, in 2007-2009 as many as 22 buoys have been distributed in Indonesian waters, but the fate of the 22 buoys since 2012 is very pathetic and cannot operate. The most significant contributing factor to the damage of it is the irresponsible human hands, and there are those who are stolen by fishermen or damaged by anchors. The success of structural mitigation is closely related to people's awareness, behavior, and culture. In this regard, non-structural mitigation efforts are deemed more appropriate to do first because they will directly involve all stakeholders' stay and living in the region. In this way, it is hoped that the community will have a sense of ownership to protect and manage the sustainability of coastal ecosystems to mitigate when a tsunami disaster comes. One of the non-structural mitigation efforts that can be carried out jointly by the government and related stakeholders is to manage and rehabilitate coastal ecosystems where this coastal ecosystem is a natural barrier to coastal areas from various threats originating from the sea, including tsunami threats. 
Regarding ecosystem-based disaster mitigation, Guannel et al., (2016) write about the importance of three coastal protective forces. Guannel et al. explained the importance of protecting natural habitats, which sometimes we unknowingly can protect coastal communities from the effects of waves and storms. The coral reef ecosystem, seagrass beds, and mangroves became the object of research by Guannel et al. Which concluded that mangroves are the most potent ecosystems to protect the coast, the presence of coral reefs and seagrass beds also has a role in reducing the impact of waves and storms, thereby further reducing the vulnerability of coastal areas. Thus, the picture that can be drawn from this research is the importance of taking an integrated approach to coastal protection efforts, especially paying attention to coastal ecosystems. As an illustration, the position of the three coastal ecosystems as a natural barrier can be seen in Figure 3.

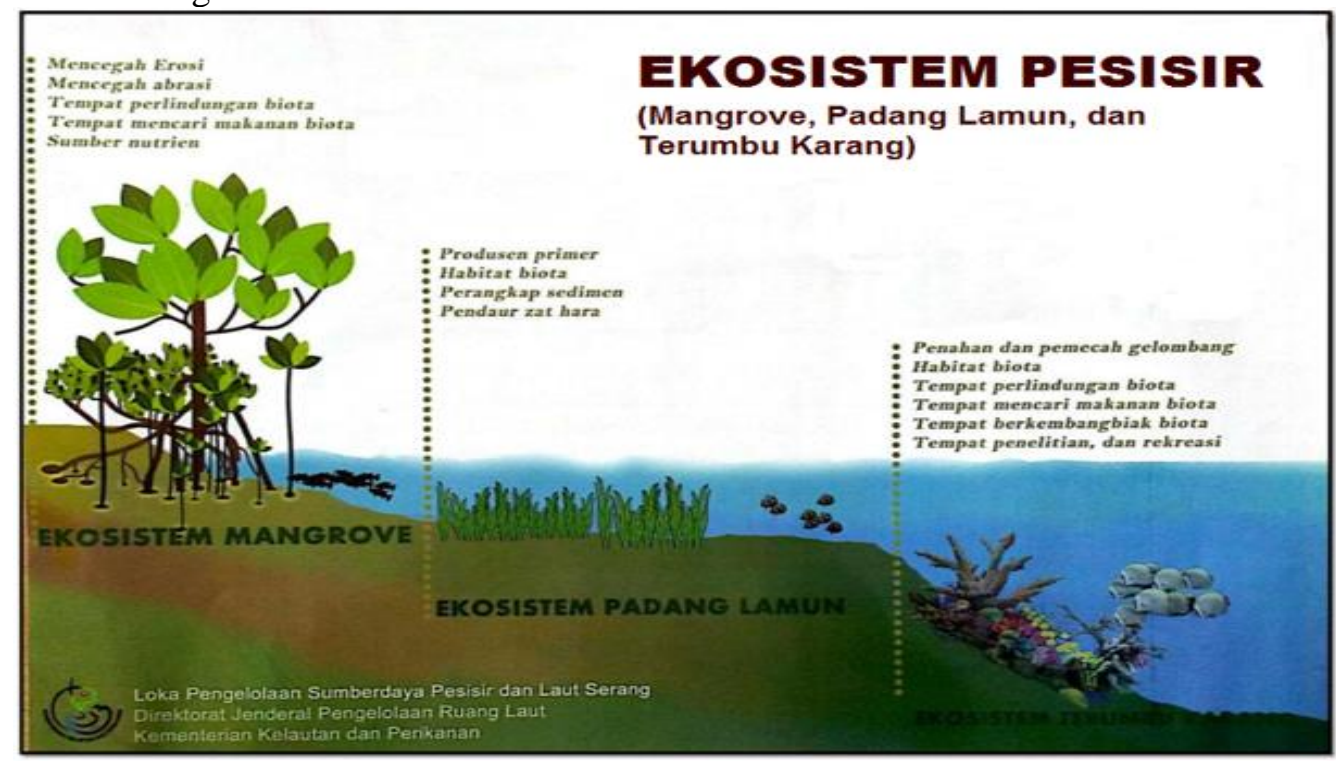

Source: KKP

Figure 3

Coastal Ecosystem

Natural barriers provided by coastal ecosystems can be useful when the condition of coastal ecosystems is in ideal and maintained condition. In addition to mangroves, coral reef ecosystems can provide protection that cannot be underestimated. Research conducted by Kunkel et al., (2006) using a simulation model states that under certain conditions, coral reefs can reduce tsunami wave speeds by up to $50 \%$ before heading to areas of seagrass beds and mangroves. The results of this study confirm that if the condition of coral reefs is in good condition and maintained, then ecosystem-based mitigation efforts will be more effectiveefficient in reducing the impacts that arise when a tsunami occurs. However, the 2018 LIPI monitoring data based on monitoring from 1,067 monitoring locations throughout Indonesia shows that coral reefs have pathetic conditions. Only $6.56 \%$ of the condition of coral reefs is stated in ideal/excellent condition. 


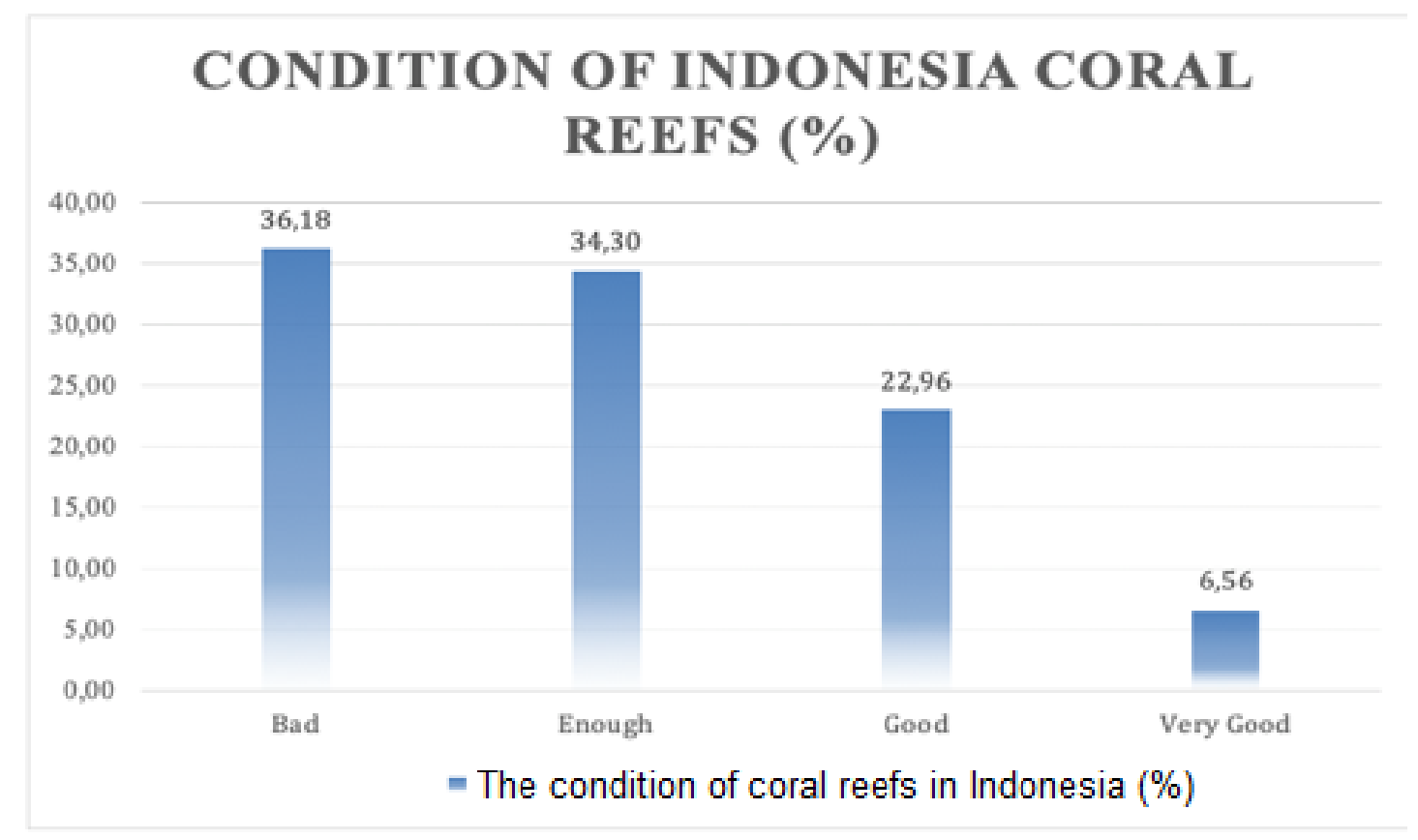

Source : LIPI (the data is processed by researchers)

Figure 4

Condition of Indonesian Coral Reefs 2018

The government will not be able to carry out mitigation efforts alone without assistance from various parties, both private/business and community, especially those living in coastal areas that are vulnerable to tsunamis. The collaboration of all stakeholders is necessary to carry out various disaster mitigation efforts so that efforts made from upstream to downstream can be implemented and synergized well, and ultimately the common goals can be achieved.

It is not easy to manage and rehabilitate coral reefs. Various interests in each stakeholder become essential to be able to work together. The synergy needed needs to contain universal principles, joint motivation, and joint action between the relevant stakeholders so that the management and rehabilitation programs and policies can run smoothly to achieve the goals to be accomplished. Based on the description above, efforts to mitigate ecosystem-based management and rehabilitation of coral reefs collaboratively are expected to provide maximum benefits that can ultimately reduce the impact when a tsunami occurs. 


\section{METHOD}

The analysis technique used in this study is a descriptive qualitative analysis by analyzing the appropriate forms of collaboration used in the management and rehabilitation of coral reefs in the efforts of tsunami disaster mitigation. The method used in gathering data and information is library research and reviewing secondary data. Secondary data is data obtained indirectly, including information related to the research. According to Sekaran (2009), secondary data can be obtained from online data, internet access, websites, document searches, or information publications.

\section{RESULT AND DISCUSSION}

After the Sunda Strait tsunami, President Joko Widodo in the National Coordination Meeting for Disaster Management BNPB in Surabaya on February 2, 2019, delivered 6 (six) directions related to the disaster that can be formulated as follows:

1. Regional development planning must be based on aspects of disaster risk reduction/mitigation, related to spatial planning and community participation in the preparation of spatial planning.

2. Involve the academics and disaster experts in research, study, and analysis of potential disasters and disaster-prone points related to disaster mitigation. Socialization must be carried out massively to the community through various means, and it can be done through religious leaders and regional governments.

3. Rapid preparedness and emergency response by the ranks of government in the region through coordination and joint action.

4. Development of an integrated early warning system with assistance and collaboration between experts, local government, central government. BNPB is asked to coordinate all relevant ministries and institutions in an early warning system to be realized and maintained together.

5. Instruct disaster education to be immediately carried out primarily in disaster-prone areas to the community, educational institutions, and religious leaders.

6. The disaster management simulations are carried out regularly and on a scheduled basis to prepare the community because a disaster can happen at any time.

President Joko Widodo's direction confirmed the importance of collaboration in carrying out disaster mitigation efforts. All relevant stakeholders must collaborate in disaster mitigation and do not prioritize their respective sectoral egos. Collaboration is a modern view that provides an overview of how stakeholders play a role and engage in public policy. Emerson and Nabatchi provide an overview of the dynamics that occur in a collaboration that includes principled involvement, shared motivation, and joint action.

The current condition is that there are still sectoral egos in each stakeholder and different views of coral reef ecosystems. Ministries/institutions that are closely related to coral reef ecosystems, only carry out their tasks and functions following the mandate given, without coordinating how they work together to formulate a more sustainable joint policy and step. The 
174 Jurnal Ilmiah Ilmu Administrasi Publik: Jurnal Pemikiran dan Penelitian Administrasi Publik Volume 10 Number 1, January - June 2020. Page 1-14

Ministry of Marine Affairs and Fisheries has a mandate as stipulated in article 5 of PP 60 of 2007 to conserve ecosystems including coral reef ecosystems, but can only carry out conservation efforts in areas that have been designated as conservation areas, and have not been oriented to disaster mitigation efforts in the region of tsunami-prone areas. LIPI, which has the mandate to carry out scientific-based work, is also only monitoring and evaluating the condition of coral reefs, and providing recommendations on what efforts should be taken if the condition of the coral reef is damaged if needed by the technical ministry. The National Disaster Management Authority (BNPB) tends to focus on disaster relief efforts after natural disasters occur, although in the organizational structure of BNPB, there is the task of mitigating nonstructural disasters, these efforts are only focused on public awareness by providing education and disaster knowledge. The private sector also has a profit-oriented interest in exploring coral reefs in running their tourism businesses or transferring land functions into hotel buildings that shift the habitat of coastal ecosystems. Then the lack of public awareness of the importance of coral reef ecosystems complements the bad luck that befalls coral reef ecosystems. The lack of knowledge of coastal communities about the benefits of larger coral reef ecosystems is neglected and tends to use coral reefs as a fishing ground to catch fish using explosives and the use of fishing gear that is not environmentally friendly.

Differences in the interests of these stakeholders need to be synergized in order to achieve optimal public goals. Riley (2002) explains that the relationships between organizations include "interaction, linkage, cooperation, operational collaboration, and critical collaboration." It can be concluded that in disaster mitigation efforts to reduce the impact of natural disasters, collaborative governance is needed. Collaboration is a relationship/cooperation between organizations (sociology), intergovernmental relations (public administration), strategic alliances (business management), multi-organization networks (public management), all four of which are interactions and relationships between organizations.

Ansell and Gash (2008) further stated the definition of Collaborative Governance as follows:

"A governing arrangement where one or more public agencies directly engage non-state stakeholders in a collective decision-making process that is formal, consensus-oriented, and deliberative and that aims to make or implement public policy or manage public programs or assets".

In line with Ansel and Gash, the importance of collaboration between stakeholders to achieve public goals, Emerson et al. (2011); Emerson and Nabatchi (2015) explains the three components that work together interactively and repeatedly to determine a collaborative action and determine efforts to achieve a common goal in a collaborative dynamic. The three components are (1) principled engagement, (2) shared motivation and (3) joint capacity. The three then made a simple approach model that was easily understood in government collaborative governance. 


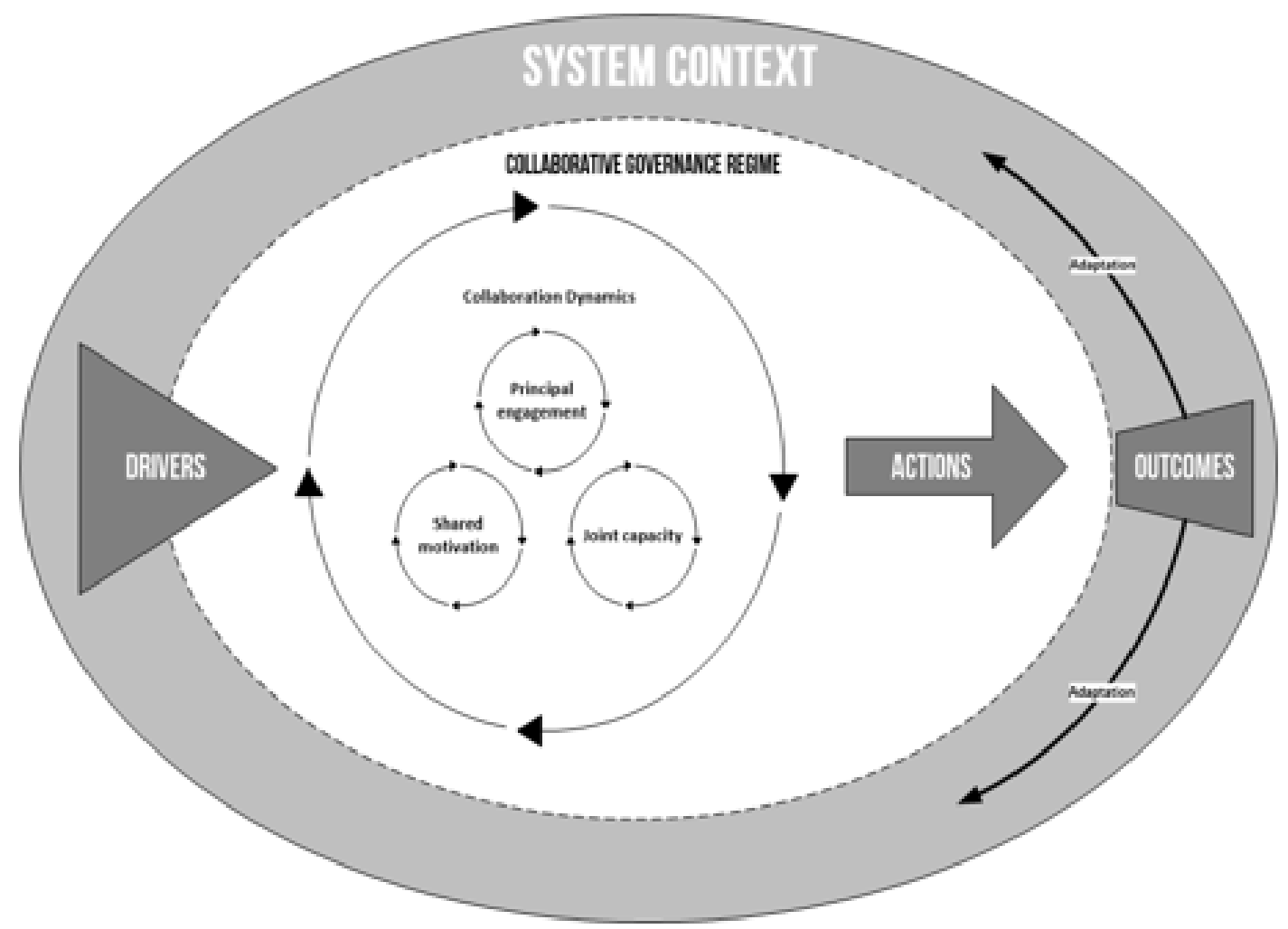

Source: Emerson and Nabatchi (2015)

Figure 5

Integrative Framework Collaborative governance

If we look at Figure 5, the concept of Collaborative Governance Regime is the main feature in this framework. Emerson uses the word "regime" to reach specific modes, systems, cross-border decision making in intensive and repetitive interactions. Emerson sees collaborative governance arises because of the encouragement of multi-partner government management consisting of cooperation between countries, civil society, society, and the private sector; or arises because of adjustments to the concept of management and partnership between government and the private sector which is often referred to as a hybrid. It confirms the importance of involving stakeholders to solicit ideas and constructive input to formulate public policies that are operational and can accommodate all the interests of the stakeholders. The government is no longer a single player, and the overlapping and sectoral ego of the stakeholders must be merged into a collaboration to deliver principled engagement, shared motivation, and collective capacity (Emerson \& Nabatchi, 2015). Next, to understand the approaching model in CGR, (Emerson \& Nabatchi, 2015) describe in the form of images and tables that explain the system context, collaborative dynamic, drivers, actions, and outcomes; as follows: 
176 Jurnal Ilmiah Ilmu Administrasi Publik: Jurnal Pemikiran dan Penelitian Administrasi Publik Volume 1o Number 1, January - June 2020. Page 1-14

Table 2

\section{A Collaborative Governance Approach Model}

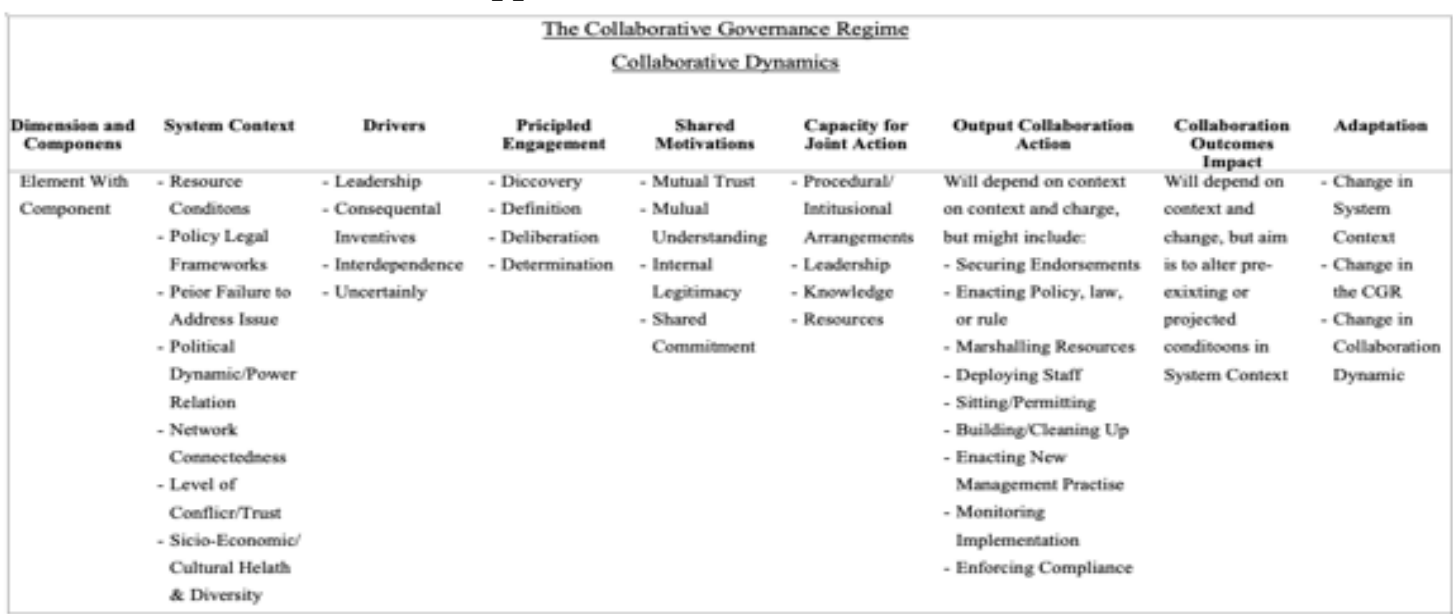

Source: (Emerson and Nabatchi 2015a; Emerson et al. 2012)

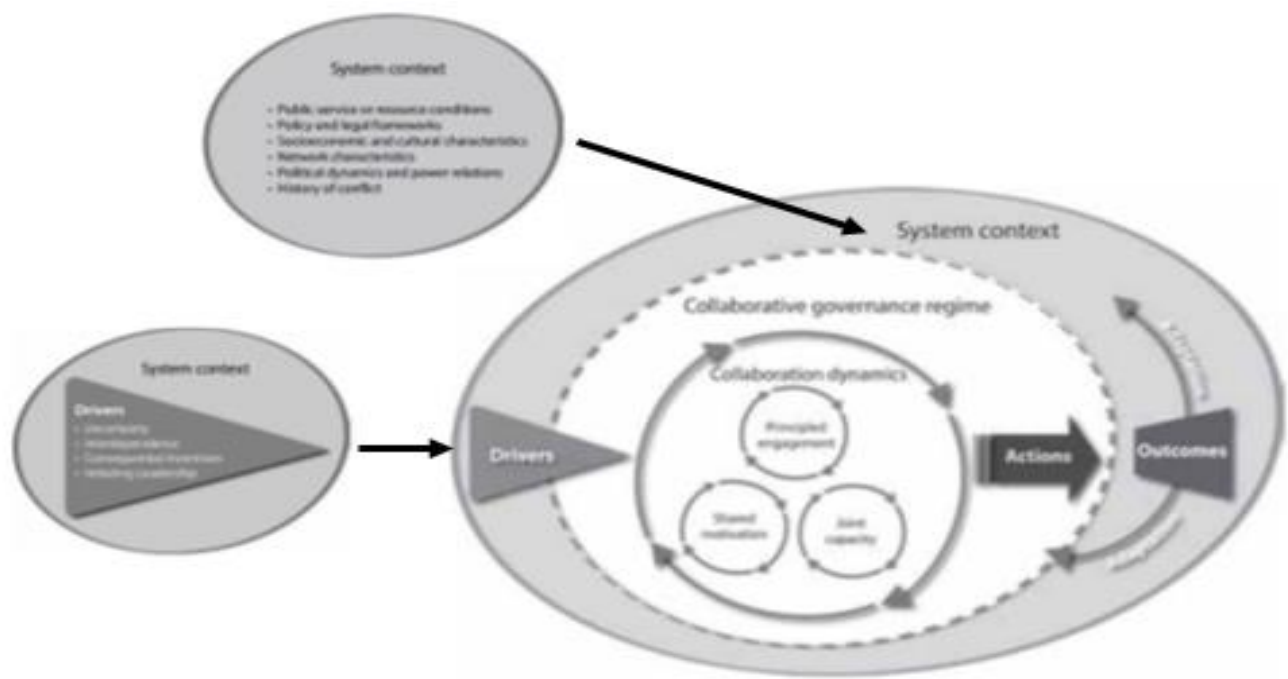

Source: Emerson and Nabatchi (2015)

Figure 6

Integrative Framework Collaborative Governance

Collaborative Governance Management and Rehabilitation of Coral Reefs in the context of Tsunami Disaster Mitigation

Collaborative governance is a new phenomenon in developing and improving public sector services. With the concept of CG, it is expected to be able to increase the participation and involvement of the public, private, and community sectors. Prof. Heungsuk Choiyang, South Korea collaborative governance expert added, three strategies can be done to reduce the 
performance gap in government, namely: (1) communicative and transparent, (2) competitive/qualified, and (3) oriented to public services. If the performance gap can be reduced, it is a good sign of good governance. The collaborative governance approach encourages every government institution to make various changes and improvements to achieve Good Public Governance (GPG). GPG is a system related to how state administrators can manage their authority in carrying out their duties with full responsibility and accountability. The principle of the GPG is to regulate the pattern of relations and procedures between the state and community organizers, state administrators, and other state institutions; and relations between countries.

Speaking of the problem of tsunami disaster mitigation based on management and rehabilitation of coral reef ecosystems, from the perspective of the mandate given to ministries/institutions can be described as follows:

1. National Disaster Management Authority (BNPB)

Law Number 24 the Year 2007 concerning Disaster Management mandates the establishment of a body that handles disaster issues specifically. Through Presidential Regulation No. 8/2008, a National Disaster Management Authority (BNPB) was formed, which was given the mandate to coordinate all ministries/institutions in implementing disaster response policies, including mitigation efforts. Non-structural mitigation efforts are also carried out by BNPB, such as undertaking awareness-raising, community preparedness, and vigilance efforts, a compilation of zones in disaster-prone areas, and simulations of disaster emergency response. Efforts that have led to the management and rehabilitation of coral reefs to build natural barriers have not yet been made.

2. Ministry of Marine Affairs and Fisheries (KKP)

Law Number 27 of 2007 as has been changed into Law Number 1 of 2014 concerning Management of Coastal Areas and Small Islands mandating the KKP to do (1) carry out disaster mitigation efforts; (2) integrated regional and small island management; (3) conserving coastal ecosystems and small islands; (4) rehabilitate ecosystems and/or biodiversity; (5) Space zoning as a form of sea space utilization engineering. Besides that, Act Number 31 of 2004 as amended to Law Number 45 of 2009 concerning Fisheries includes coral reefs as one of the categories of fish and ecosystems that must be protected.

3. Local Government.

Based on Law Number. 23 of 2014 concerning Regional Government, in terms of carrying out concurrent affairs together with the central government, including environmental, marine and fisheries affairs. In this Law, the provincial, regional government has 2 (two) functions at the same time, namely (1) as an autonomous region, and; (2) as a representative of the central government in the regions.

4. Indonesian Institute of Sciences (LIPI).

LIPI as a government institution based on Presidential Decree Number 103 of 2001 organized affairs in the field of science. Coral reef monitoring is one of the tasks that must be carried out by LIPI.

The mandate related to the management and rehabilitation of coral reef ecosystems, as outlined in the legislation, has spread across several ministries and institutions. However, until now, there has been no form of collaboration that is accommodated in one forum and involves 
178 Jurnal Ilmiah Ilmu Administrasi Publik: Jurnal Pemikiran dan Penelitian Administrasi Publik Volume 10 Number 1, January - June 2020. Page 1-14

all relevant stakeholders. State institutions, technical ministries, and regional governments in their respective capacities tend to carry out their duties and functions partially and not in a joint manner to obtain good synergy.

Then other actors directly involved in the implementation of coral reef management and rehabilitation policies in efforts to mitigate coral reef-based ecosystems are the private sector and the community. The private sector, as a profit-oriented actor (profit), must also be involved in the matter. The form of tourism business managed by the private sector in coastal and marine areas is inseparable from the "tourism menu" of underwater natural beauty. Marine biodiversity is a unique attraction for domestic and foreign tourists. Not to mention the construction of supporting facilities and infrastructure for tourism activities such as the construction of hotels, cafes, places to eat, and others which are not infrequently done by way of land conversion, which sacrifices many coastal ecosystems.

Community misunderstanding, especially those living in coastal and marine areas, is complementary to sufferers who cause poor coastal ecosystem conditions. Lack of community awareness of the importance of coastal ecosystems, which are natural barriers, makes people tend to explore the marine biodiversity that is not environmentally friendly. The use of bombs/explosives to catch fish, the use of fishing gear that is not environmentally friendly, and people's habits that tend to dispose of their waste into the sea make it a "giant trash bin." The result of this human activity causes coastal ecosystems, especially coral reefs, unable to survive and function as natural barriers.

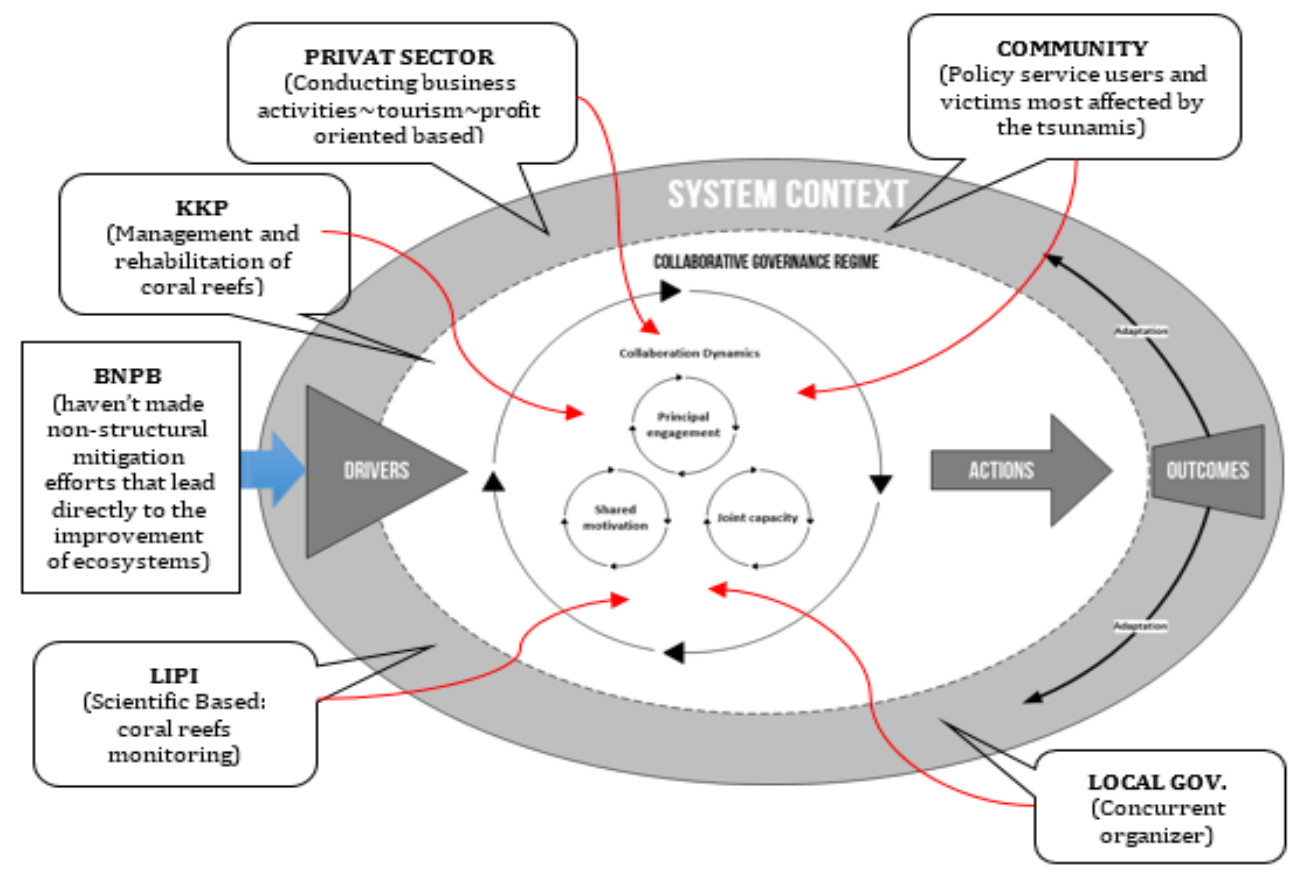

Figure 7

Application of Collaborative Governance Theory (Emerson and Nabatchi 2015) in efforts to mitigate coral reef ecosystem-based tsunamis. 


\section{CONCLUSION}

From the results of the analysis related to the concept of collaborative governance (Emerson and Nabatchi 2015) management and rehabilitation of coral reefs in the efforts to mitigate tsunami, the following conclusions can be drawn: 1) Collaboration between stakeholders, management, and rehabilitation of coral reefs in efforts to mitigate natural disasters of the tsunami has not been well established and is still sectoral. It happens because no collaboration platform can accommodate the interests of each actors involved, 2) The existence of a collaboration forum that can accommodate and synergize interests is expected to produce principles of engagement, shared motivation, and joint action, which will ultimately have an impact on the implementation of programs and policies that are more implementable, right on target and earn the common goals to be achieved, and 3) BNPB as a state institution given the mandate to coordinate mitigation efforts that may be carried out in coastal areas to reduce the impact of the tsunami as a natural disaster cause the most losses both social and economic aspects have not conducted intensive and ongoing coordination with the ministry/ related institutions, regional government, private sector, and community.

\section{REFERENCES}

Amagai, T., Ichimaru, S., Tai, M., Ejiri, Y., \& Muto, A. (2014). Nutrition in the Great East Japan Earthquake Disaster. Nutrition in Clinical Practice, 29(5), 585-594. https://doi.org/10.1177/0884533614543833

Ansell, C., \& Gash, A. (2008). Collaborative governance in theory and practice. Journal of Public Administration Research and Theory. https://doi.org/10.1093/jopart/mum032

Bragg, C., Gibson, G., King, H., Lefler, A. A., \& Ntoubandi, F. (2018). Remittances as aid following major sudden-onset natural disasters. Disasters, 42(1), 3-18. https://doi.org/10.1111/disa.12229

Bullock, J. A., Haddow, G. D., \& Coppola, D. P. (2011). Introduction to homeland security: Principles of all-hazards risk management. Butterworth-Heinemann.

Bumgarner, J. B. (2008). Emergency management: a reference handbook. ABC-CLIO.

Emerson, K., \& Nabatchi, T. (2015). Collaborative governance and collaborative governance regimes. Collaborative Governance Regimes.

Emerson, K., \& Nabatchi, T. (2015). Collaborative governance regimes.

Emerson, K., \& Nabatchi, T. (2015). Evaluating the productivity of collaborative governance regimes: A performance matrix. Public Performance \& Management Review, 38(4), 717747.

Emerson, K., Nabatchi, T., \& Balogh, S. (2012). An integrative framework for collaborative governance. Journal of Public Administration Research and Theory. https://doi.org/10.1093/jopart/mur011 
180|Jurnal Ilmiah Ilmu Administrasi Publik: Jurnal Pemikiran dan Penelitian Administrasi Publik Volume 1o Number 1, January - June 2020. Page 1-14

Guannel, G., Arkema, K., Ruggiero, P., \& Verutes, G. (2016). The power of three: coral reefs, seagrasses and mangroves protect coastal regions and increase their resilience. PloS One, $11(7)$.

Kunkel, C. M., Hallberg, R. W., \& Oppenheimer, M. (2006). Coral reefs reduce tsunami impact in model simulations. Geophysical Research Letters, 33(23).

Neumayer, E., \& Plümper, T. (2007). The Gendered Nature of Natural Disasters: The Impact of Catastrophic Events on the Gender Gap in Life Expectancy, 1981-2002. Annals of the Association of American Geographers, 97(3), 551-566. https://doi.org/10.1111/j.14678306.2007.00563.x

Porter, M., Skinner, T. D., \& Wheelans, M. A. (1967). Structural characterization of vulcanizates. Part VIII. The N-cyclohexylbenzothiazole-2-sulfenamide-accelerated sulfur vulcanization of natural rubber at $140-180^{\circ} \mathrm{C}$. and of synthetic cis-1,4-polyisoprene at $140^{\circ} \mathrm{C}$. Journal of Applied Polymer Science, 11(11), 2271-2283. https://doi.org/10.1002/app.1967.070111114

Riley, J. M. (2002). Stakeholders in Rural Development: Critical Collaboration in State-NGO Partnerships. Sage Publication, 97. https://doi.org/10.1023/A:1022081926076

Rossi, P. H., Wright, J. D., Weber-Burdin, E., Pietras, M., \& Diggins, W. (1982). Natural hazards and public choice. Elsevier.

Sekaran, U. (2009). Research methods for business 4th edition. Hoboken. NJ: John Wiley \& Sons.

Sorooshian, S. (2005). Meeting the challenges of natural hazards in the wake of the tsunami disaster. Eos, Transactions American Geophysical Union, 86(2), 14. https://doi.org/10.1029/2005EO020005

Yamamura, E. (2013). Natural Disasters and Participation in Volunteer Activities: A Case Study of the Great Hanshin-Awaji Earthquake. Annals of Public and Cooperative Economics, 84(1), 103-117. https://doi.org/10.1111/apce.12005

Yanagisawa, H., Goto, K., Sugawara, D., Kanamaru, K., Iwamoto, N., \& Takamori, Y. (2016). Tsunami earthquake can occur elsewhere along the Japan Trench-Historical and geological evidence for the 1677 earthquake and tsunami. Journal of Geophysical Research: Solid Earth, 121(5), 3504-3516. https://doi.org/10.1002/2015JB012617 